\title{
On maritime transport costs, evolution, and forecast
}

Gerardo Polo ${ }^{1}$

\begin{abstract}
During recent years of economic euphoria, globalization, motor of development, has been possible due to the existence of a fast, efficient, and economic maritime transport. The technological development based on scale economies, improvement of cargo-handling systems, and specialization has allowed putting on the market vessels with very competitive costs. In these years of a bright freight market, increased costs seemed not to be of much concern, so that the problem was not approached with the necessary firmness. Nowadays, things have changed: freight rates have sunk, prices of ships have fallen, and the crisis has reached ship owners. The costs, nevertheless, are still rising, with the exception of 2009 in which, for the first time in ten years, costs of operations were sensibly reduced. In the paper, the evolution of the main components of the costs of the maritime transport are analyzed, studying the current situation of such, as well as the forecasts for the near future.
\end{abstract}

Key words: Maritime transport, Costs, Globalization, Operation costs, Opex

\section{Resumen}

En los pasados años de euforia económica, la globalización, motor del desarrollo, ha sido posible gracias a la existencia de un transporte marítimo rápido, eficiente y económico, propiciado por un desarrollo tecnológico basado en las economías de escala, la mejora de los medios de carga y descarga y la especialización. Ello ha permitido poner en el mercado buques con costes muy competitivos, cuyo incremento, en un boyante mercado de fletes parecía no preocupar demasiado, por lo que no se le hizo frente con la necesaria firmeza. Hoy en día, las cosas han cambiado: los fletes se han hundido, los precios de los buques han caído y la crisis ha alcanzado a los navieros. Los costes, sin embargo, han seguido su línea ascendente, con la excepción del año 2009, en el que, por primera vez en diez años, se experimentó una reducción sensible de los costes de operación. En el trabajo se analiza la evolución de los principales componentes del coste del transporte marítimo, la situación actual de éstos, así como las previsiones para el futuro próximo.

Palabras claves: Transporte marítimo, Coste, Globalización, Costes de operación, Opex

Date Received: December 9th, 2010 - Fecha de recepción: 9 de Diciembre de 2010

Date Accepted: February 9th, 2011 - Fecha de aceptación: 9 de Febrero de 2011

${ }^{1}$ Escuela Técnica Superior de Ingenieros Navales. Universidad Politécnica de Madrid. Madrid, España. e-mail: gerardo.polo@upm.es 


\section{Introduction}

The operating costs of ships have traditionally been a topic difficult to investigate for lack of reliable data. In fact, at the beginning of my professional life, many ship owners thought that it was too delicate a matter and were reluctant to furnish said data, even in relative terms. Fortunately, things have changed and nowadays there are trustworthy sources providing valuable information to study the evolution of those costs. And this is a matter of maximum importance because, in a globalized market, such as that of the maritime transport, competitiveness is the main weapon that allows ship owners to reach the comparative advantages against their competitors. Of course, it is quite necessary to have benchmarking data with regard to what is being done in other places -often very different, very distant, and with cultures and ways of life very diverse from ours. This way, one can get at least a base to build the business framework to develop the shipping activity.

On the contrary, important changes that have taken place in nearly all economic sectors, but especially in the maritime sector, as a consequence of the world economic crisis, have produced significant modifications in the operating costs of ships, which have to be considered not only by the ship owners, who carry out the activity of maritime transport, but also by the rest of the participants of the maritime industries: shipyards, auxiliary industry, ports, etc., whose managerial developmentis strongly tied to that of the shipping activity and, therefore, pressed for all things that affect it.

Namely, in the past years, an important escalation of costs has taken place in the international maritime market, which has led a great number of ship owners to situations of difficult survival. Does this have something to do with the rest of the maritime industries stated above? Certainly yes, because ship owners have ordered the building of new vessels in shipyards and the continuity of the work is seriously threatened by the financial situation of the former; the auxiliary industry, ship suppliers, etc., also creditor of the ship owners; and of course banks, who granted credits for the construction of ships, credits that can be difficult to recover; for the world trade, whose exports and imports depend mainly on the availability of maritime transport that is not only efficient, but specially economic and reliable, among others.

It again places on the table the problems of the operating costs of ships, a matter of enormous importance for ship owners and for the whole international economy. This is why we decided to present this paper on the operating costs of maritime transport, its evolution throughout the past years and the forecasts that, nowadays, experts in the sector conduct for the future evolution of these costs.

\section{The cost structure of maritime transport}

The traditional subdivision of the operating costs of ships between fixed costs and voyage costs is well known.

In fact, according to the classical subdivision of maritime economics, costs can be divided as far as the production volume is concerned and so the costs are considered fixed when they are independent from the above-mentioned volume and variables when they depend on the same one. Nevertheless, it is difficult to find in maritime transport costs of voyages that are really proportional to magnitudes related to production: namely, and always with some restrictions, the bunker consumptions could to be considered as proportional to the distance -or to the time employed to cover them at a certain speed-and certain costs relative to the loading/ unloading of cargo proportional to the transported tonnage or, perhaps better, moved in every port; on the other hand, it is not clear at all what should be considered to be the production volume in the maritime transport: the transported tons?, the miles navigated?, the produced tons? the crossed miles?, the product of tons by miles? These are the reasons why it is best to refer not to the production volume, - difficult to fix in the maritime transport-, but to the level of activity, concept into which the different above referred magnitudes can fit with more precision. 
Thus, the cost of maritime transport can be classified as fixed costs and variable costs (in our case, voyage costs); within these, some of their components can be considered proportional to magnitudes more or less related to the level of activity. Independent from the previous ones, there are costs of sales, which are generally proportional to the earnings or commissions on the sales, but these are often considered a reduction of income, which are entered by the net amount.

From a strictly theoretical point of view, the fixed costs, independent from the activity developed, remain constant even though there is no activity; in other words, though the ship remains idle. But, as far as our classification is concerned, we will recognize as fixed costs those whose objective is to maintain the ship in seaworthy conditions to offer transport services, even though the vessel can be laid-up. So, the ship must have its crew on board, certificates in order, engines in operating conditions, insurance policies in order, etc., (aspects to a certain extent damaged when a ship is really laid-up). Bearing in mind these issues, the fixed costs will really have such a character, and it will only be necessary to add the voyage costs to obtain the total costs.

The voyage costs -or variable costs- are a function of the activity the ship develops, taking place only when the vessel is in service. Unlike the fixed costs, they depend on every specific voyage and, especially, on the ports of call, distance crossed, cargo handling operations, the possible need of passing some channels, etc.

Within the fixed costs it is necessary to distinguish the capital costs-CAPEX, costs derived from the property of the ship-and the running costs or fixed operation costs -OPEX, costs that are necessary to have the vessel ready for operation-: by means of both types of costs the operator fulfils his basic aim already indicated of having the ship seaworthy to give the service of transport. Depreciation and financial costs are the capital costs; and crew, insurance, maintenance and repairs and the administration costs are the running costs or operation costs.
Certainly, as soon a voyage starts, the ship owner incurs in voyage costs, costs that can be classified into a single category of voyage costs or segregating from them the cargo-handling costs.

The voyage costs, always depending on the specific trip, are costs inherent in the activity of the operator, that is to say, they are costs for the ship owner or the time charterer to develop the maritime activity of the voyage.

Among the voyage costs, the following items are usually distinguished: the bunkers consumptions, port costs, channel tolls, and cargo-handling costs.

Ships in the open tramp market usually do not assume cargo handling costs, as they are chartered on FIOST conditions, but when ships are on regular service, the ship owner includes in the freight the cost of handling the goods for loading and unloading. In the regular services, voyage costs are also fixed, as the ships repeat itineraries and scales, so port costs and channels tolls, as well as bunker costs are fixed costs and the cargo handling costs are the only variable costs.

\section{Dependence factors}

In any case, a brief analysis of the above referred cost structure shows that a very important part of the fixed costs is a direct function of the building cost of the ship (through depreciation, interests and insurance costs), though the rest depends on multiple factors of diverse types. On the other hand, the main components of the voyage costs -that can be grouped in two big items: bunker consumption during the navigation time and costs produced during the stay in port- depend, to a great extent, on the speed of the ship, the prices of the fuel and the time of stay in port.

So, the most important factors of the maritime transport costs show something simple, but often forgotten. That time of navigation, time in port, and cargo handling costs constitute the basic framework of costs of the shipping economy. All this based on a few technical factors of the costs -speed, specific consumptions, general arrangement 
Table 1. Cost structure of maritime transport

\begin{tabular}{|c|c|c|}
\hline Tramp & Cost Concept & Regular Lines \\
\hline & $\begin{array}{l}\text { Costs of capital } \\
\text { - Depreciation of the ship } \\
\text { - Interests of financing credits } \\
\text { - } \quad \text { Other financial costs }\end{array}$ & \multirow{3}{*}{ Fixed Costs } \\
\hline Fixed Costs & $\begin{array}{l}\text { Running costs or fixed operation costs } \\
\text { (OPEX) } \\
\text { - Crew } \\
\text { - Maintenance and Repairs } \\
\text { - Insurance } \\
\text { - Administrations costs } \\
\text { - } \quad \text { Proportional costs } \\
\end{array}$ & \\
\hline Voyage Costs & $\begin{array}{l}\text { Bunker consumption } \\
\text {-Non-proportional costs } \\
\text { - Port costs } \\
\text { - Chanel tolls } \\
\text { - Other }\end{array}$ & \\
\hline Voyage Costs (eventually) & $\begin{array}{ll}\text { - } & \text { Cargo handling costs } \\
\text { - } & \text { Taxes and other cargo costs } \\
\text { - } & \text { Multimodal equipment } \\
\text { - } & \text { Land transport }\end{array}$ & $\begin{array}{l}\text { Cargo-related Costs } \\
\text { Cost of Special Systems } \\
\text { (eventually) }\end{array}$ \\
\hline
\end{tabular}

of ship and cargo handling systems (on board and in port, infrastructure)- and a few economic factors on which, once the ship is on operation, it is difficult or impossible to be changed or, in any case, action on these is very limited -fixed costs of the ship, fuel prices, costs of port, cargo handling costs-. All of them outline the final cost structure of the maritime transport. Schematically, it is possible to put:

Table 2. Technical and economics factors of maritime transport

\begin{tabular}{|c|c|c|}
\hline & Technical factors & Economic factors \\
\hline Navigation & $\begin{array}{ll}\text { - } & \text { Ship's speed } \\
\text { - } & \text { Specific consumptions }\end{array}$ & $\begin{array}{ll}\text { - } & \text { Fixed cost of ship (daily) } \\
\text { - } & \text { Bunkers price }\end{array}$ \\
\hline Stay in Port & $\begin{array}{l}\text { General arrangement and cargo } \\
\text { handling system (ship and port) } \\
\text { - Specific consumptions }\end{array}$ & $\begin{array}{ll}\text { - } & \text { Fixed cost of ship (daily) } \\
\text { - } & \text { Bunkers price } \\
\text { - } & \text { Port expenses } \\
\text { - } & \text { Cargo handling costs }\end{array}$ \\
\hline
\end{tabular}

As far as the economic factors is concerned, it must be clear that ship owners have very few possibilities of modifying them to act on the evolution of their costs, so the factors on which those depend are, fundamentally, the price of acquiring the ship, its financing conditions, and a series of factors completely beyond the ship owner's influence, given that they are imposed by the market of crude oil and of marine fuels, the ports, etc.; only, but with numerous limitations, ship owners can act on their fixed costs of operation (crew, maintenance and repairs, insurance, etc.); the rest of the costs escape the action of ship owners, who can do nothing to control them.

And as for the technical factors, it is quite clear 
that, except the eventual alterations in the general arrangement of the ship to adapt it better to the traffic giving her some specific cost saving system or an improvement of the productivity, such as the installation of new cranes to make a better performance of cargo handling operations, from a practical point of view the shipowner only can modify his costs by means of the alteration of the service speed, and to this respect, the slow steaming is a good proof of it.

In any case, it can be seen that probably the main specific characteristic of the costs of maritime transport is the remarkable inflexibility, which is one of the major difficulties to face the traditional crises of the freight market.

\section{Evolution of costs}

During the last years, and up to the great economic crisis begun in the middle of 2007 and generalized on the following year, and affecting the whole international economy, the freight market, basis of the globalization, grew up to unbelievable levels in many years, with values of the indexes that had never been reached before. In this context, during these years of prosperity, the costs - nearly all the costs- grew very remarkably. And the shipowners, more attentive to the freight market than to their internal costs did not fight against this problem so important for them.

First of all, the rise of the fuel prices is well-known, whose evolution during recent years was really devastating for the shipping economy: the 380 Cst fuel oil, whose price in Rotterdam in 2003 reached 150 US Dollars per metric ton, reaching 720 US Dollars per metric ton in 2008, when the price of the barrel of crude oil reached 146 US Dollars. And though later the pressure diminished, we are now in a new upward stage, with fuel oil prices that at the beginning of January, this year have surpassed 500 US Dollars per metric ton, so the invoice of the bunkers continues being very high, and the lines of big container ships have reduced the speed of service, incorporating new vessels in their lines, while the oil tankers are also considering to reduce their speeds and to return to the slow steaming.
On the other hand, the evolution of the Euribor during the last years has become another important factor in the increase of the costs, in this case the capital costs. In fact, the average of the one year Euribor, which in 2003 was $2.34 \%$, was $3.44 \%$ in 2006, 4.45\% in 2007, and in 2008 it went beyond 5.50\%. That led, between 2003 and 2008, to cost increases of interests close to $130 \%$, which translated to increased needs for cash flow to take care of the debt between 12 and 13\%. Fortunately, the fall of interest rates from the generalization of the crisis has again reduced the capital costs, which are now even below those existing in 2003, in spite of the light recovery produced in Euribor during recent months. Anyhow, at the end of this year, or maybe during the following year, substantial increases of interest rates will be seen once more, given that as soon as the economies recover their production pace, the danger of inflation will have to be attacked by means of a new increase of interest rates.

But it has not been only a problem of fuel or financial costs. Also, other costs of operation mainly crew, maintenance and repairs, supplies and insurance - have followed the rise of those costs. The year 2007 was particularly sensitive to these increases: according to Moore Stephens (7), the average increase of the costs of crew was over $10 \%$, though in some types of ships the figures reached were above that percentage - namely, the container ships saw a $20 \%$ increase in this item. Costs of supplies also experienced important increases, over $16 \%$, though below the figure of the previous year, which reached a $20 \%$ increase. As far as maintenance and repairs are concerned, the average increase in 2007 was 12\%, though with differences among the different types of ships. And the insurance costs also rose, experiencing an average $7 \%$ increase. Globally, the average increase of the costs of operation of the fleet through the year 2007 was $11.2 \%$.

But it has not only been a matter of one year. Between 2003 and 2008 -the years of the freight market boom -the running costs of operation of the ships (crew, maintenance and repairs, insurance, etc.) endured very important increases. The following table shows the representative indexes 
of operations costs of bulk carriers, oil tankers, and container ships between 2000 and 2008, as well as the year-on-year percentage variations (also according to Moore Stephens).

As noted, the total increase of costs of operation during only eight years have been very important, namely $72 \%$ for bulk carriers and $84 \%$ for oil tankers. The container ships, whose statistics only reach 6 years, saw their costs grow to $73 \%$. Percentages that correspond to rates of annual accumulative growth of costs between $7.0 \%$ and $9.6 \%$, absolutely unbearable figures except under situations of a freight market boom; otherwise, they can collapse the economies of a great majority of ship owners.

Table 3. Evolution of running costs of operation of ships

\begin{tabular}{|c|c|c|c|c|c|c|}
\hline & \multicolumn{2}{|c|}{ Bulk Carriers } & \multicolumn{2}{|c|}{ Oil Tankers } & \multicolumn{2}{|c|}{ Container Ships } \\
\hline & Index & $\%$ Change & Index & $\%$ Change & Index & $\%$ Change \\
\hline 2000 & 100 & & 100 & & & \\
\hline 2001 & 101 & $1,0 \%$ & 106 & $6,0 \%$ & & \\
\hline 2002 & 96 & $-5,0 \%$ & 109 & $2,8 \%$ & 100 & \\
\hline 2003 & 105 & $9,4 \%$ & 113 & $3,7 \%$ & 110 & $10,0 \%$ \\
\hline 2004 & 118 & $12,4 \%$ & 125 & $10,6 \%$ & 117 & $6,4 \%$ \\
\hline 2005 & 122 & $3,5 \%$ & 132 & $5,6 \%$ & 120 & $2,6 \%$ \\
\hline 2006 & 135 & $10,0 \%$ & 144 & $9,1 \%$ & 133 & $10,8 \%$ \\
\hline 2007 & 145 & $7,4 \%$ & 160 & $11,1 \%$ & 157 & $18,0 \%$ \\
\hline 2008 & 172 & $18,0 \%$ & 184 & $15,0 \%$ & 173 & $10,2 \%$ \\
\hline$\Delta$ annual cum. & & $70,0 \%$ & & $7,9 \%$ & & $9,6 \%$ \\
\hline$\Delta$ total & & $72,0 \%$ & & $84,0 \%$ & & $73,0 \%$ \\
\hline
\end{tabular}

Fig. 1. Evolution of Index of Commodities and Baltic Dry Index

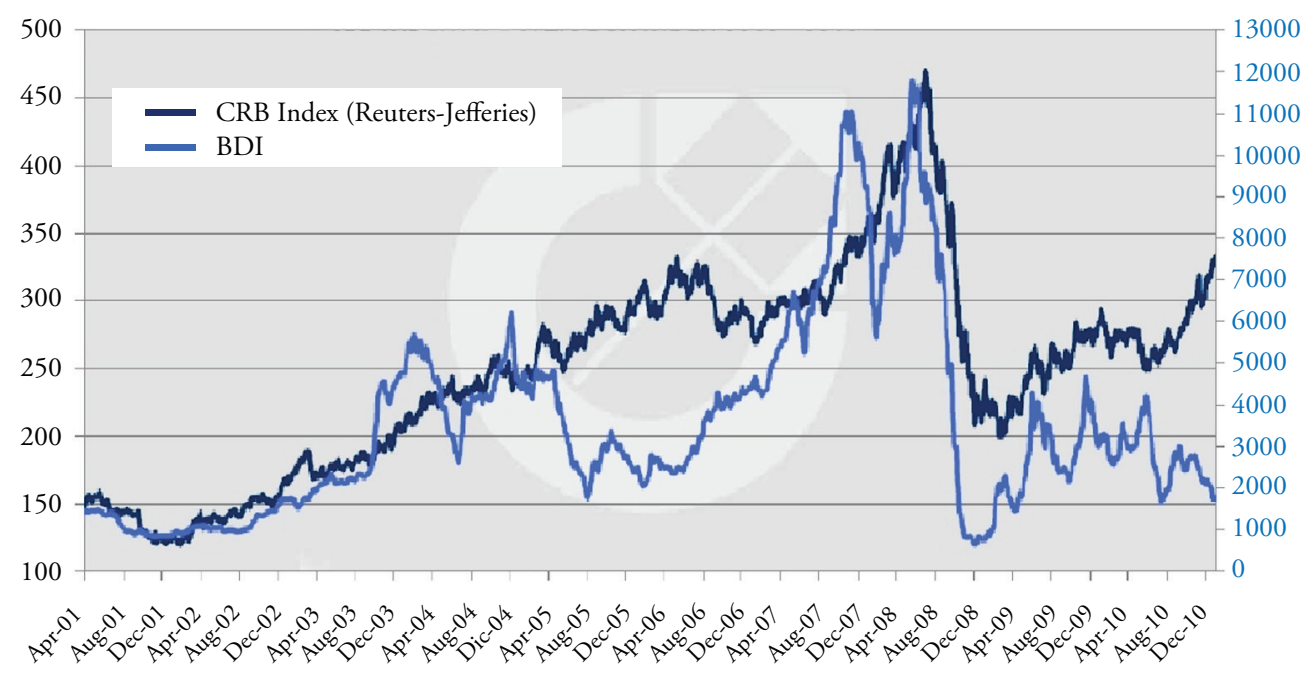


What is the reason for such an important rise in costs? Simply because at the same pace of the growth of the economies of most countries, the prices of raw materials also rose in a immoderate way, so that not only the fuels -whose multiplier effect on the prices is clear and important -, but also aluminum, copper, nickel, silver, etc., that is to say, the main commodities of international trade, were multiplying their prices and their influence on the world economy. Especially, the evolution of the prices of coal, iron ore, and steel have had muchrelevance in this explosion of price increases.
Actually, the behaviour of the main commodities during these years was very much alike that of the BDI (Baltic Dry Index), which is considered to be the most suitable measure of the evolution of the freights corresponding to the dry bulk goods on the world market. A remarkable correlation can be observed, according to Cotzias, between the BDI and the CRB Index Reuters-Jefferies, considered one of the most accurate indexes of raw materials on the international trade market.

Fig. 2. VLCC Costs 1990-2010

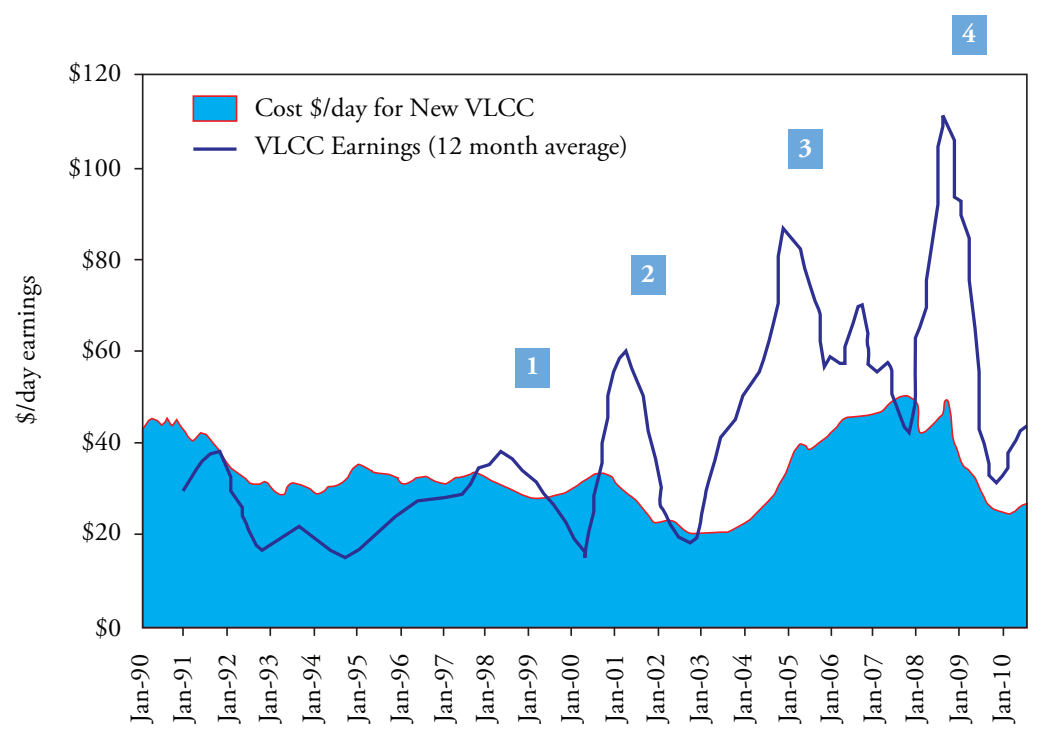

Fig. 3. Cape Costs 1990-2010

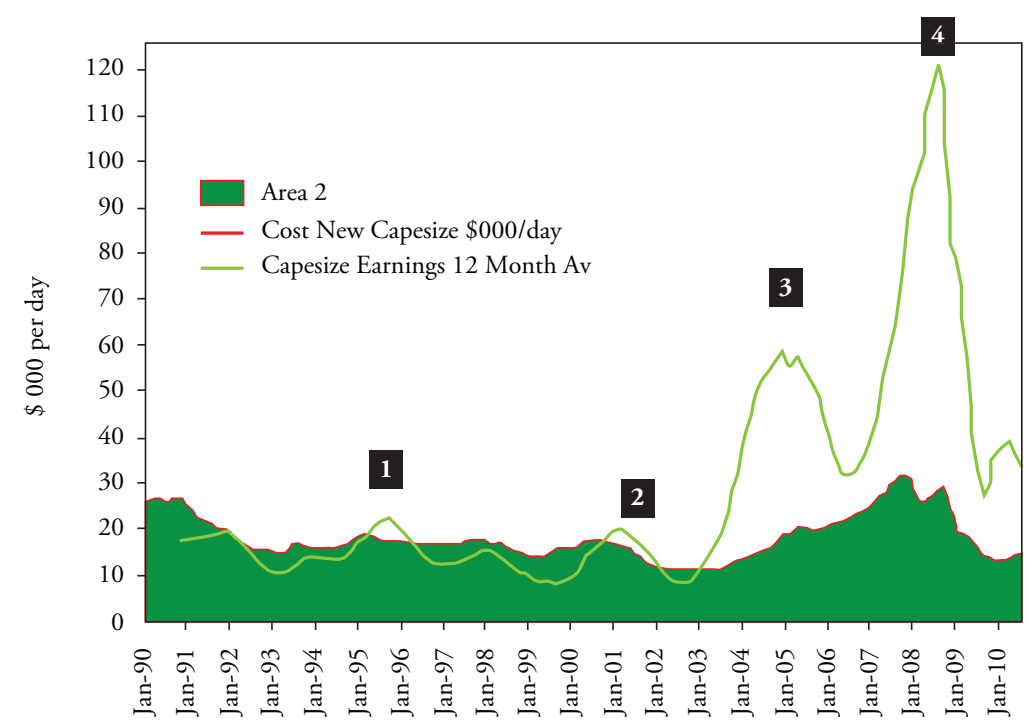


Fig. 4. TEU Container Costs 1994-2010

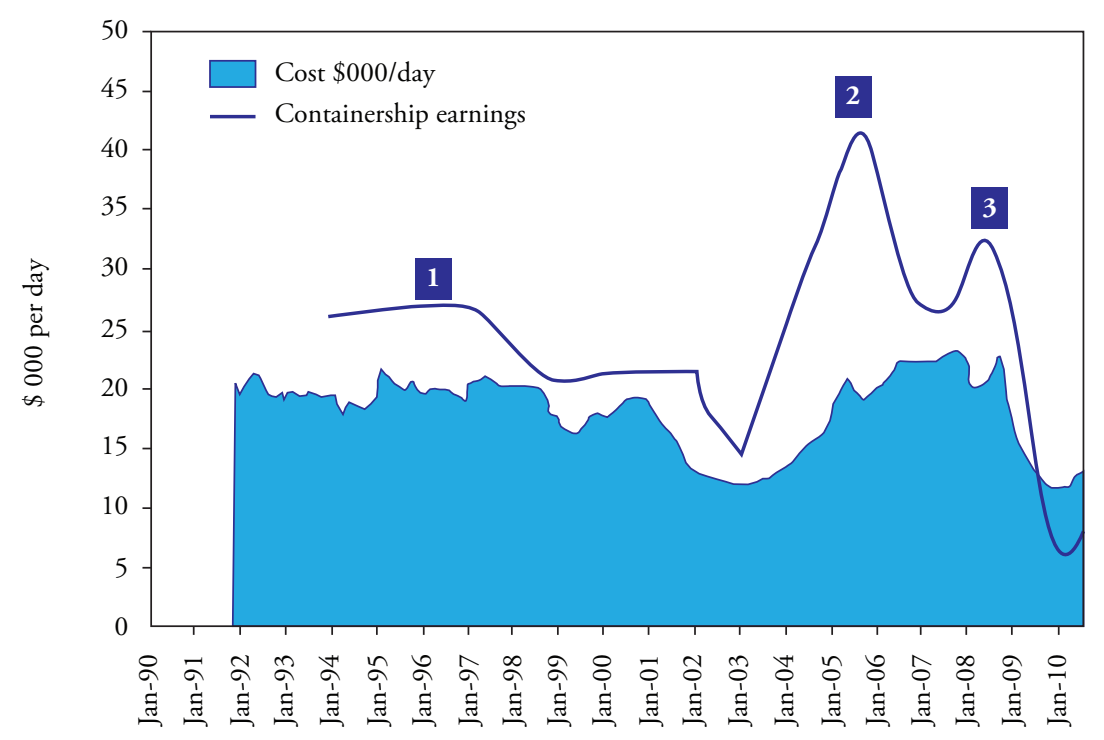

On the other hand, it is certainly interesting to observe the evolution of the fixed total costs of operation of ships (capital costs plus operation costs) throughout the last 20 years, according to Clarksons (information presented by Stopford at the end of last year 2010). These calculations were made with capital costs computed on a 20 -year depreciation period, interest at Libor rate, and all calculations referred to the price of a new building in every month of the year.

The information corresponding to three types of ships (VLCC oil tanker, Capesize bulkcarrier and 3.300 TEUs containership) is illustrated in the lower part of the graphs, that show in US\$/day the total cost of each type of ship, in front of the curve of the corresponding income (TCE), left apart in this moment. In this figures we can see that between 2003 and 2008, the years of the freight boom, the total costs per day of the ships grew between 100\% (3300 TEUs containership) and 200\% (VLCC oil tanker and Capesize bulkcarrier) to a great extent because, besides the rising of the operation costs, the capital $\operatorname{costs}^{1}$ also suffered an important augment.

\section{Summary and forecast}

The costs of operating a ship, which, as explained above, can be divided into fixed costs and voyage costs, have experienced remarkable growths especially important since 2003. Let us summarize their evolution.

The capital costs depend mainly, as explained before, on the purchase price of the ship. This is a parameter closely correlated with the evolution of freight index. In the years of the last boom, astronomic prices were paid not only for new ships or ships still being built in the shipyard -between $50 \%$ and $100 \%$ above the price of the shipyard for a newbuilding-, but, in addition, in the second hand market prices reached figures higher to those corresponding to newbuildings -bulk carriers 5 and 10 years old and some 5 years old oil tankersand even old ships of 20 years of age, were sold at prices between $75 \%$ and $80 \%$ of the newbuilding prices by those dates. We refer to the first half of the year 2008. This was possible because the market was paying extraordinarily high freights which allowed a very quick recovery of the capital, in spite of that the old ships required an annual income much higher than the new ones to face to the capital payments (devolution of principal and interests of the debt). The information included has been taken from Compass (3) and corresponds to October, 2007, but figures were even higher in the first half of 2008. 
Table 4. Newbuilding and second hand prices of ships in October 2007

\begin{tabular}{|c|c|c|c|c|c|c|}
\hline Tankers & NB & $\begin{array}{c}\text { Prompt } \\
\text { Resale }\end{array}$ & 5 Years & 10 Years & 20 Years & $\begin{array}{c}12 \text { Month } \\
\text { T/H }\end{array}$ \\
\hline VLCC $300,000 \mathrm{dwt}$ & $\$ 143,0 \mathrm{~m}$ & $\$ 153,0 \mathrm{~m}$ & $\$ 133,0 \mathrm{~m}$ & $\$ 105,0 \mathrm{~m}(\mathrm{DH})$ & $\$ 33,0 \mathrm{~m}(\mathrm{SH})$ & $\$ 50,000 \mathrm{PD}$ \\
\hline Suezmax $150,000 \mathrm{dwt}$ & $\$ 88,0 \mathrm{~m}$ & $\$ 105,0 \mathrm{~m}$ & $\$ 96,0 \mathrm{~m}$ & $\$ 75,0 \mathrm{~m}(\mathrm{DH})$ & $\$ 26,0 \mathrm{~m}$ & $\$ 42,000 \mathrm{PD}$ \\
\hline Aframax $105,000 \mathrm{dwt}$ & $\$ 70,0 \mathrm{~m}$ & $\$ 78,0 \mathrm{~m}$ & $\$ 67,0 \mathrm{~m}$ & $\$ 55,0 \mathrm{~m}(\mathrm{DH})$ & $\$ 20,0 \mathrm{~m}(\mathrm{SH})$ & $\$ 32,000 \mathrm{PD}$ \\
\hline Panamax $70,000 \mathrm{dwt}$ & $\$ 64,0 \mathrm{~m}$ & $\$ 66,0 \mathrm{~m}$ & $\$ 56,0 \mathrm{~m}$ & $\$ 48,0 \mathrm{~m}(\mathrm{DH})$ & $\$ 17,0 \mathrm{~m}$ & $\$ 27,500 \mathrm{PD}$ \\
\hline Product $47,000 \mathrm{dwt}$ & $\$ 52,0 \mathrm{~m}$ & $\$ 58,0 \mathrm{~m}$ & $\$ 53,0 \mathrm{~m}$ & $\$ 43,0 \mathrm{~m}(\mathrm{DH})$ & $\$ 17,0 \mathrm{~m}$ & $\$ 25,000 \mathrm{PD}$ \\
\hline
\end{tabular}

\section{Bulk Carriers}

\begin{tabular}{|c|c|c|c|c|c|c|}
\hline Capesize $170,000 \mathrm{dwt}$ & $\$ 96,0 \mathrm{~m}$ & $\$ 160,0 \mathrm{~m}$ & $\$ 133,0 \mathrm{~m}$ & $\$ 101,0 \mathrm{~m}$ & $\$ 72,0 \mathrm{~m}$ & $\$ 185,000 \mathrm{PD}$ \\
\hline Panamax $74,000 \mathrm{dwt}$ & $\$ 50,0 \mathrm{~m}$ & $\$ 100,0 \mathrm{~m}$ & $\$ 84,0 \mathrm{~m}$ & $\$ 71,0 \mathrm{~m}$ & $\$ 40,0 \mathrm{~m}$ & $\$ 89,000 \mathrm{PD}$ \\
\hline Supramax $52,000 \mathrm{swt}$ & $\$ 43,0 \mathrm{~m}$ & $\$ 84,0 \mathrm{~m}$ & $\$ 72,0 \mathrm{~m}$ & $\$ 56,0 \mathrm{~m}$ & $\$ 34,0 \mathrm{~m}$ & $\$ 67,000 \mathrm{PD}$ \\
\hline
\end{tabular}

Source: Compas

Evidently, the fall of the market has been a hard knock for the shipowners, many of which have not been able to support the new conditions, some have been led to sell their ships with big losses and others even have disappeared. Banking also suffered much of the problem, as financial basis of the investments, and many financial institutions have been immersed in the crisis. Certainly, the fall of the market has also brought a better price of the ships, though the financing of them has become much more difficult to obtain and the number of operations has been reduced.

Fig. 5. OPEX indexes evolution 2000-2010

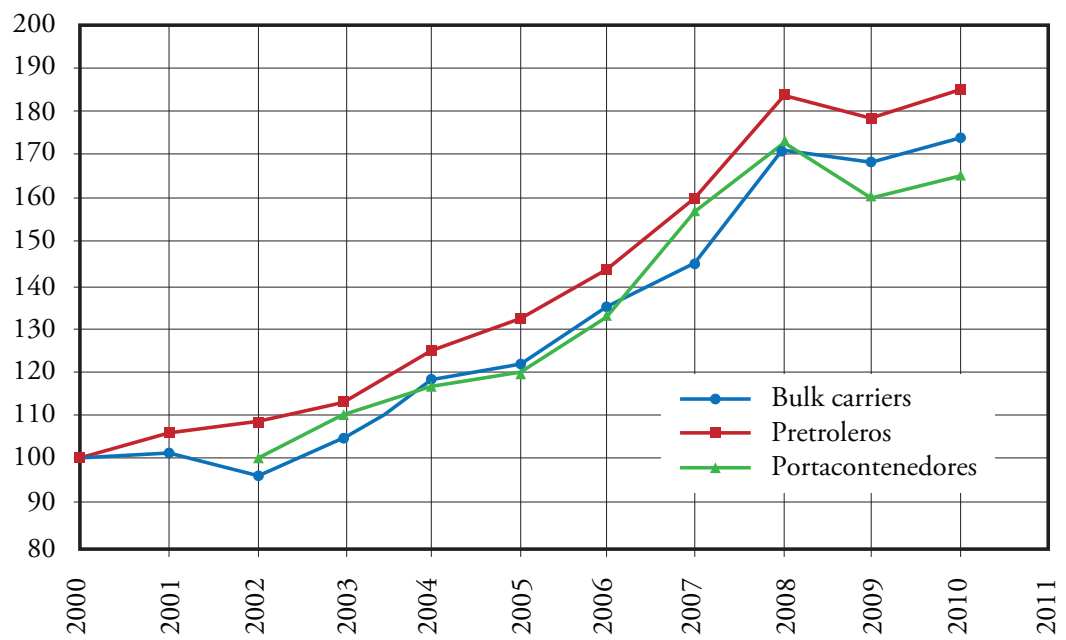

Anyhow, every ship is a particular case, and has acquired ships at different prices, in different although the general evolution of prices has been moments and with different financing conditions. the indicated one, the fact is that every ship owner 
The evolution of the running costs or fixed costs of is that in the middle of the crisis -although with operation (Opex) of ships during the last 10 years the exception of the year 2009- the costs continue shows a nearly continuous rise. The problem now increasing.

Fig. 6. Evolution of crude oil price and bunker price in Rotterdam

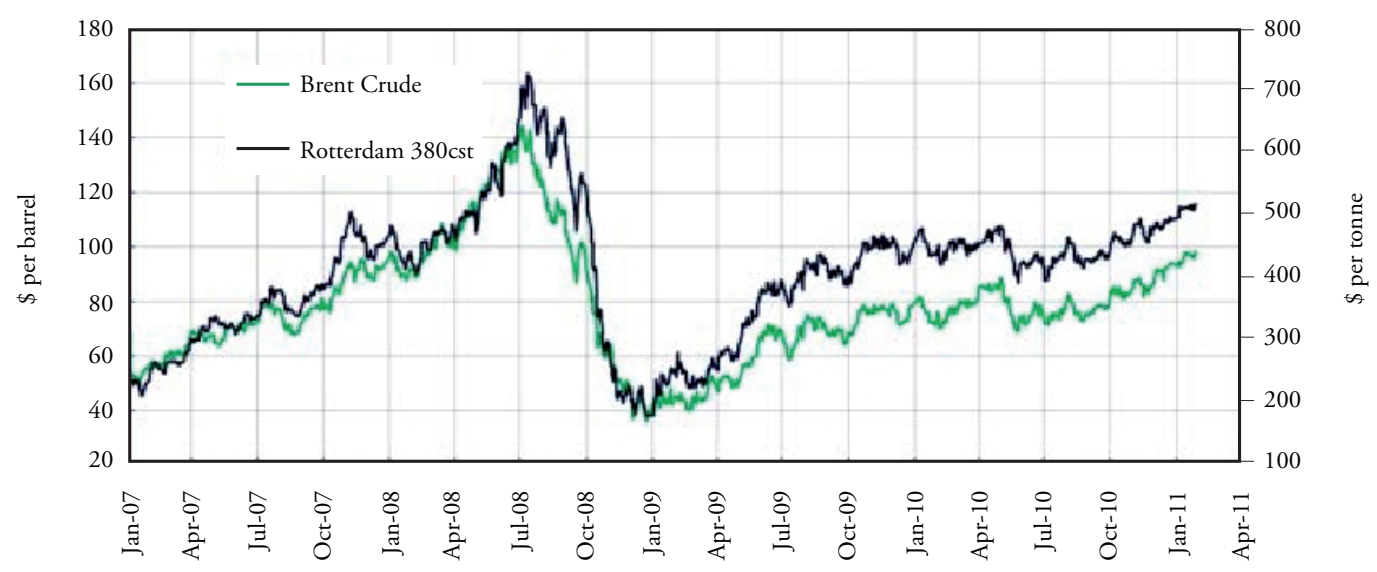

Fig. 7. Calculation of tce of VLCC RAS TANURA / CHIBA

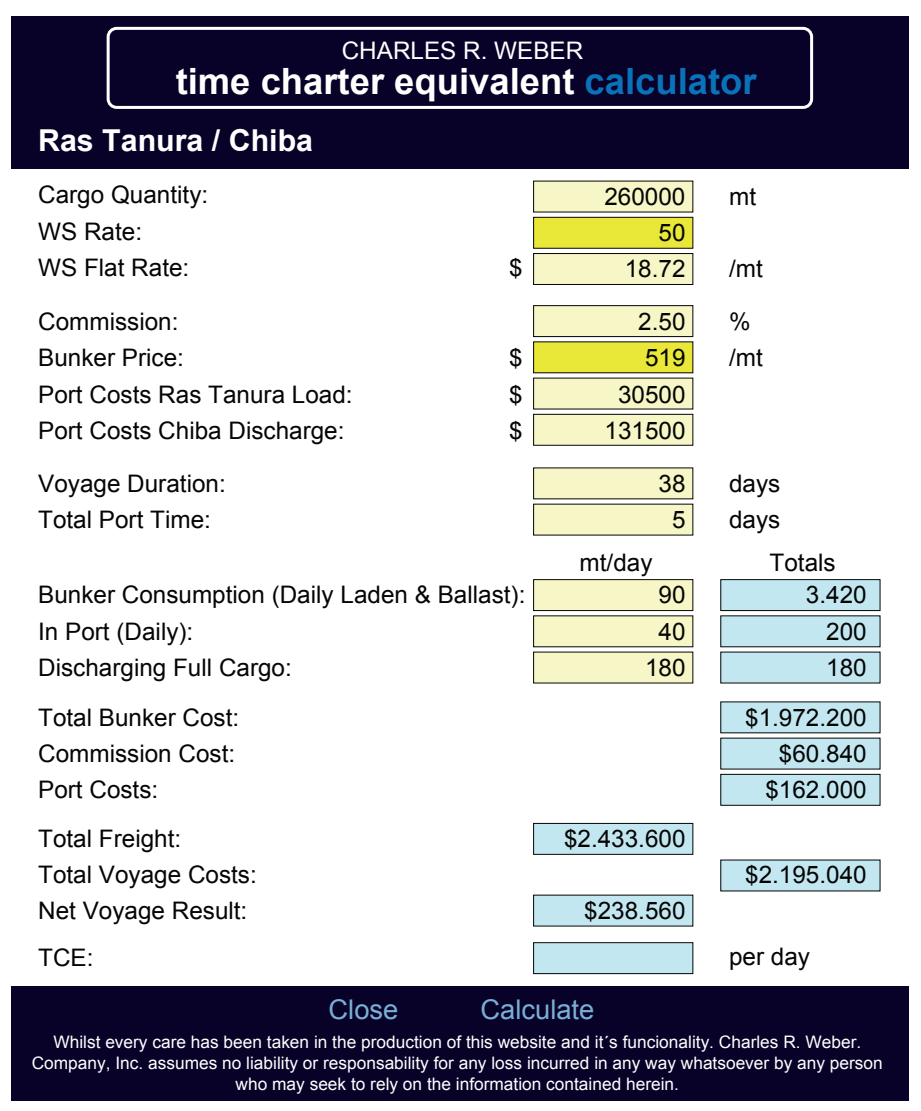

Nowadays, with information at the beginning of January, 2011, some oil tankers are in a serious situation, as the calculation of the TCE at the WS rates in force in the above-mentioned date shows that in a trip Ras Tanura - Chiba the fuel consumed by a VLCC has a cost equivalent to $75 \%$ of the 
gross freight [source: Charles R. Weber (2)] and the TCE is below 10,000 US\$/day, which means that the ship does not cover its daily running costs.

The fact is that already the price of a metric ton of fuel-oil is on 510 dollars $^{2}$ and slow steaming continues spreading. Namely, after the first cut to about 20 knots in the regular lines of big container ships, widely extended in the above mentioned market, and a the second fall to 17,2 knots, shipowners are now studying the proposal of Germanischer Lloyd -supported by Bureau Veritas- of limiting the speed of these vessels to approximately 14 knots -although someone is also talking about going to just 12 knots-, in what it has been called super-slow steaming.

All that has a decisive importance in the relations between supply and demand, according to Danish Ship Finance (5) the artificial or apparent reduction of supply due to the slow steaming to 20.2 knots gave employment for big container ships in 2009 of about 1.200.000 TEUs; whereas, a new fall of the speed of operation of the post-panamax container ships to just 17.2 knots generates additional employment for about 1.900 .000 TEUs. So, bearing in mind that the excess of supply of big container ships, with information up to September, 2010 is about 3.600.000 TEUs (26\% of the existing fleet), the evolution of the market of big container ships, with an apparent recovery in the last months, shows simply an adjustment between supply and demand derived, not from the increase of the latter, but from the decrease of the fleet productivity and, therefore, from the artificial reduction of the former by means of slow steaming.

Up to now, we have seen mainly what happened until the collapse of the freight market, which took place in the middle of 2008. But, what happened in 2009? This year was the first after a long time in which the running costs of ships diminished; not too much, but appreciably. Namely, in the bulk carrier sector there was a reduction of $2.3 \%$, leaving the index at 168 , in the oil tanker group the decrease was $2.7 \%$, with the index remaining at 179 , and in the container ships the cost drop was more important, at $7.5 \%$, placing the index at 160 .

This is, as far as bulk carriers and oil tankers is concerned, slightly below Drewry's forecasts (6), whose calculations for the year 2009 gave a cost reduction of $3.6 \%$ and of $3.5 \%$, respectively; also, in container ships the figures are well above Drewry's predictions, whose average is $3.9 \%$.

And what about the year just finished? In 2010, the costs rose again, in spite of the depth of the crisis in the maritime sector since 2008. Though we have no definitive data, the estimations show growth of the fixed costs of operation of $3.3 \%$ in bulk carriers, $3.1 \%$ in oil tankers, and of $3.2 \%$

Fig. 8. Effect of low steaming on container regular lines offer

3,6 million teu entered the fleet from 2008 to 2010 (September 2010)

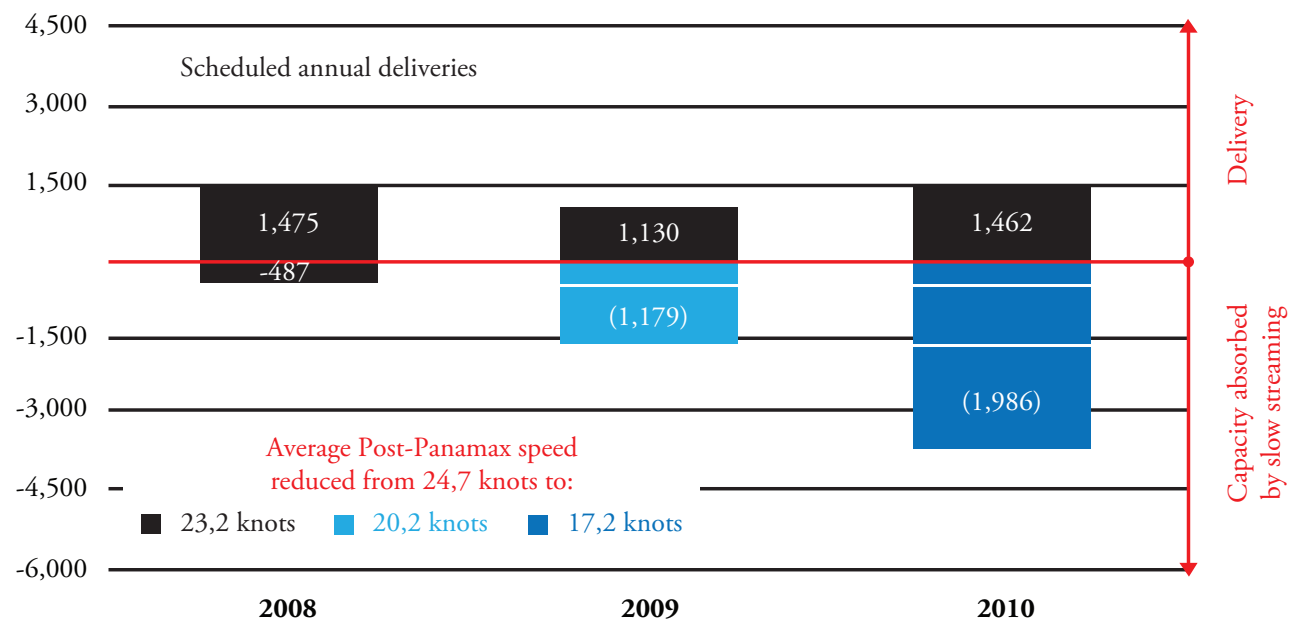


in container ships. And still worse are that the forecasts for the current 12 year, 2011, whose figures are not optimistic at all: increased costs of $3.6 \%$ in bulk carriers, $3.2 \%$ in oil tankers, and of $4.0 \%$ in container ships.

In contrast, for 2010 Drewry's predictions give minimal growth, practically a maintenance of the costs of 2009 and for 2011 major growth, near 2 to $3 \%$, but also below Moore Stephens's estimations.

Where are we going in the present circumstances, with increasing costs and important reduction of freight rates? I think we are again going to live something already lived in other past crises, which led the maritime sector to situations of real distress, with significant economic losses, lay-up of vessels, scrapping, cancellation of building contracts, unemployment in shipyards, etc., circumstances that we are already seeing since more than two years ago.

\section{References}

BRAEMAR SEASCOPE. Market Information, Jan 2011.
C. R. WEBER. The Weber Report, Jan 2011.

COMPASS. Compass Weekly Report, Oct 2007.

COTZIAS. Economic Outlook Dec 2010.

DANISH SHIP FINANCE. Shippping Market Review, Oct 2010.

DREWRY. Ship Operating Costs 2009-2010.

MOORE STEPHENS. Op Cost 2010 Report and other previous Reports.

STOPFORD. A year of decisions for shipping How will the markets develop?, FT Deutchland Ship Finance Conference, Hamburg, Sep 2010.

G. POLO. Capital Costs vs. Cash Flow: Keys to a better understanding of the freight market, Infomarine, No. 190, October 2011 
${ }^{1}$ Detailed calculations with standard international market data on capital costs for vessels with prices ranging from 40 to 120 million dollars (29 to 87 million euro), with external financing and straight- line depreciation with a residual value of $10 \%$ the price of the ship after an useful life of 20 years, lead to the estimate of capital costs and payments schematically shown in the Figure below.

Capital Costs and Payments

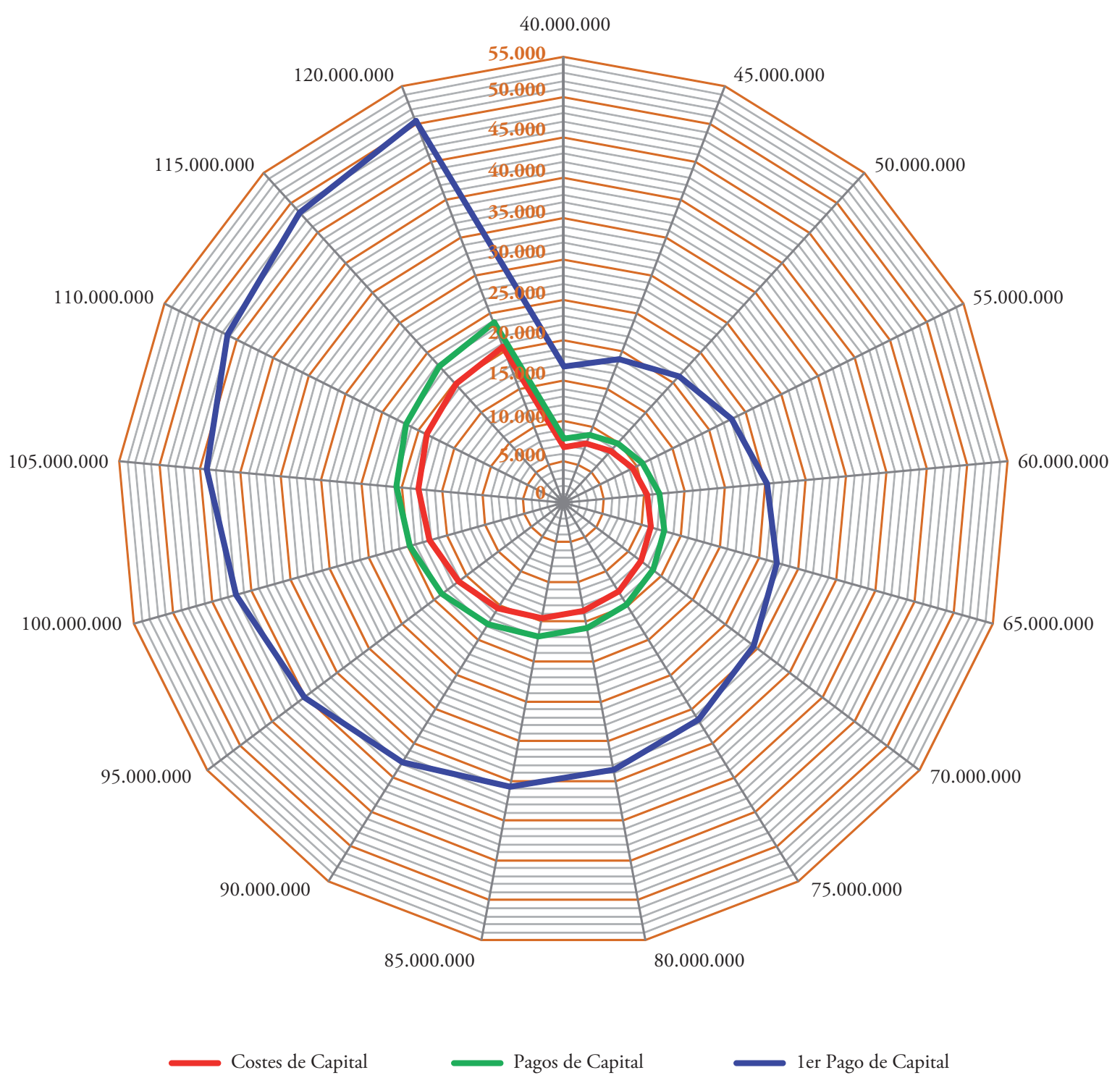

This shows the average capital cost, the average capital payment and the highest capital payment (which corresponds to the first year after the purchase) in dollars per day for different purchase prices ranging from 40 to 120 million dollars ( 29 to 87 million euro). This note is taken from Reference 9.
${ }^{2}$ One year later (first quarter of 2012), the price per metric ton was about or nearly 200 dollars higher, and it continues this tendency. 